\title{
The Media Spectacle of a Techno-City: COVID-19 and the South Korean Experience of the State of Emergency
}

\section{JAEHO KANG}

This essay provides a critical observation of the South Korean government's distinctive management of COVID-19 with particular reference to the state of emergency. It reveals that the success of South Korea's handling of the pandemic is largely attributed by a majority of Western media to the efficient deployment of both information and communication technologies and Confucian collectivism, two components that seem contradictory yet not incompatible under the rubric of techno-Orientalism. Analyzing the intensification of surveillance and the rapid datafication of society, this essay argues that the current state of emergency is not a breakdown of normality but a continuation of the state of crisis and disaster that rules a developing country like South Korea. In doing so, the essay seeks to facilitate a critical discussion about a new mode of democracy in the era of pandemic that increasingly grapples with tensions between individual freedom and public health.

Keywords: COVID-19, media spectacle, Orientalism, datafication, surveillance, state of emergency

\section{TEChNo-Orientalism}

$\mathrm{O}_{1}$ MAY 9, 2020, I received an emergency alert text message transmitted to my cell phone by the Korean Centers for Disease Control and Prevention (KCDC). The message, known as a CBS (Cellular Broadcasting Service), an unblockable message system, urged people who had visited five night clubs and bars in Itaewon-a popular nightlife district in Seoul, South Korea's capital-between April 24 and May 6 to selfquarantine and to visit a local medical center for a COVID-19 test, regardless of clinical symptoms. I received similar texts four times that afternoon.

On May 5, the South Korean government further relaxed social distancing rules. There were only three new cases that day, all of which were from abroad. This was a sharp drop from the peak of 909 new cases on February 29. Since the country's first confirmed case, reported on January 20, COVID-19 had resulted in 10,804 cases and 254 deaths as of May 5, but the spread seemed to be under control and nearly flattened. Since late April, single-digit numbers of new coronavirus cases had been reported daily with no deaths. Then, on May 8, a twenty-nine-year-old male tested positive after visiting several locations in Itaewon, including gay nightclubs, on the night of May 1

Jaeho Kang (jaekang@snu.ac.kr) is Associate Professor of Communication at Seoul National University. 
and the early hours of May 2. That the spike of nearly 100 new infections was directly linked to gay nightclubs sparked widespread blame of the "promiscuous gay lifestyle." The marked increase in homophobic backlash against the LGBTQ community via internet trolling exemplifies a typical cultural response of Asian countries depicted by the Western mainstream media.

South Korea's handling of COVID-19 has been hailed by the majority of Western media. National Public Radio touted South Korea's approach, grounded in conducting rapid, extensive testing for the coronavirus, as a model for other countries. ${ }^{1}$ An article in the New Yorker illustrated that the South Korean government's approach to combating the coronavirus made the American response look "absurd." Echoing highly positive accounts, the New York Times identified a few lessons from the South Korean model to contain the coronavirus without shutting down the economy and asked whether these could work abroad, particularly in the United States. ${ }^{3}$

South Korea may deserve some credit for its handling of the coronavirus. Among numerous indications, it is striking that the nation has had a significantly lower mortality rate from COVID-19 than other countries. As of May 26, South Korea's rate was 2.40 percent (269 deaths out of 11,225 cases), whereas most Organisation for Economic Co-operation and Development (OECD) countries, particularly in Western Europe, were higher than 10 percent. ${ }^{4}$ It is noteworthy that this was achieved without draconian restrictions on speech and movement, as imposed in China, or drastic measures such as locking down entire cities or regions, as deployed in European countries and the United States. Highlighting that the first confirmed cases of COVID-19 were reported in both the United States and South Korea on January 20, 2020, the Guardian reported that in the two months that followed, the responses by the two countries were polar opposites. ${ }^{5}$ In a similar vein, the Nation gave an account of South Korea's success in "testing, national health care, and transparency," while contrasting it with the struggle of the United States, where the death toll exceeded 112,000 as of June 8, 2020. ${ }^{6}$

${ }^{1}$ Anthony Kuhn, "Experts Credit South Korea's Extensive Testing for Curbing Coronavirus Spread," National Public Radio, March 12, 2020, https:/www.npr.org/2020/03/12/815097813/ experts-credit-south-koreas-extensive-testing-for-curbing-coronavirus-spread (accessed June 6, 2020).

${ }^{2}$ Colin Marshal, "The Comports of South Korea's Coronavirus Response," The New Yorker, April 14, 2020, https://www.newyorker.com/news/dispatch/the-comforts-of-south-koreas-coronavirusresponse?fbclid=IwAR2k5EOUHMUwlzIAB6MgwjJaYrcKB8-pENpvliJLOh7xud0D848PRLanHqw (accessed June 6, 2020).

${ }^{3}$ Max Fisher and Choe Sang-Hun, "How South Korea Flattened the Curve," New York Times, March 23, 2020, https://www.nytimes.com/2020/03/23/world/asia/coronavirus-south-korea-flattencurve.html?fbclid=IwAR3gM6G9QrqRQYtJjeBbhihr0SML6nelFvdSj12Cu6AVz65i9vyCsYJuOGQ (accessed June 6, 2020).

${ }^{4}$ Center for Evidence-Based Medicine, "Global Covid-19 Case Fatality Rates," https://www.cebm. net/covid-19/global-covid-19-case-fatality-rates/ (accessed May 31, 2020).

${ }^{5}$ Ed Pilkington and Tom McCarthy, “The Missing Six Weeks: How Trump Failed the Biggest Test of his Life," The Guardian, March 28, 2020, https://www.theguardian.com/us-news/2020/mar/28/ trump-coronavirus-politics-us-health-disaster (accessed June 6, 2020).

${ }^{6}$ Tim Shorrock, "How South Korea Triumphed, and the US Floundered, over the Pandemic," The Nation, March 20, 2020, https://www.thenation.com/article/world/coronavirus-south-koreaamerical (accessed June 6, 2020). 
Analyses of South Korea's management commonly attribute its success to both the efficient deployment of information and communication technologies (ICTs) and the Confucian collectivism of obedience and conformity. For instance, comparing the application of different policies in South Korea and Italy as the divergent strategies of "East vs. West," the Wall Street Journal underscored that, unlike individualistic societies, South Korea's Confucian cultural tradition enables a "paternalistic state" to intrude into people’s lives freely during a period of emergency. ${ }^{7}$ Les Echos, the oldest French financial newspaper, featured an opinion column arguing that the French government should not sacrifice individual freedoms by adopting the tracking measures deployed by South Korea, a totalitarian country with "a culture of hyper-surveillance and denunciation." The Asia Times, a Hong Kong-based news platform, stressed that Confucian Asian countries were winning the war against COVID-19 while Western countries were losing the battle with "fear, panic and hysteria."

The portrayal of Korea as a Confucian patriarchal country-that is, a hierarchical, homogeneous, monolithic, traditional, and collectivist society in Asia-is not only found in media outlets but also resonates in a more sophisticated and philosophical way among prominent intellectuals. For instance, in the fight against the pandemic, Han Byung Chul, the Korean German philosopher, contended that Asian countries such as South Korea, Japan, China, Taiwan, and Hong Kong have a systematic advantage in dealing with the pandemic in comparison with their European counterparts because they are culturally "Confucian, authoritarian and more obedient than in Europe."10 Views on South Korea's handling of the coronavirus that stress either the cultural traits of Confucian collectivism or the technological aspects of governmentality might seem contradictory, but they are not totally incompatible. In view of "techno-Orientalism," Asia and Asians are stereotypically imagined as technologically advanced but morally and intellectually primitive. ${ }^{11}$ In fact, the image of the Confucian techno-nation has been increasingly present within the media spectacle of South Korea.

The patriarchal, obedient, and collectivist image has long served notable filmic representations of South Korea. Since East Seoul (1972), the first Hollywood film that illustrated 1960s Seoul, South Korea has largely been portrayed as a struggling industrial country that remains in shambolic order since the Korean War yet maintains its indigenous and local mores and traditions. In some films, North Korea plays a crucial role as a reminder that there is a more totalitarian regime on the peninsula. The Hollywood film industry has occasionally chosen Korea as a host (at least an intermediate host, if not the

\footnotetext{
${ }^{7}$ Timothy W. Martin and Marcus Walker, "East vs. West: Coronavirus Fight Tests Divergent Strategies." Wall Street Journal, March 13, 2020.

${ }^{8}$ Virginie Pradel, "Covid-19 et traçage: Ne sacrifions pas nos libertés individuelles!," Les Echos, April 6, 2020, https://www.lesechos.fr/idees-debats/cercle/opinion-covid-19-et-tracage-ne-sacrifions-pas-nos-libertes-individuelles-1192463 (accessed June 6, 2020).

${ }^{9}$ Pepe Escobar, "Confucius Is Winning the Covid-19 War," Asia Times, April 13, 2020, https://asiatimes.com/2020/04/confucius-is-winning-the-covid-19-war/ (accessed June 6, 2020).

${ }^{10}$ Byung-Chul Han, "Wir dürfen die Vernunft nicht dem Virus überlassen," Die Welt, March 23, 2020, https://www.welt.de/kultur/plus206681771/Byung-Chul-Han-zu-Corona-Vernunft-nichtdem-Virus-ueberlassen.html (accessed June 6, 2020).

${ }^{11}$ David S. Roh, Betsey Huang, and Greta A. Niu, eds., Techno-Orientalism: Imagining Asia in Speculative Fiction, History, and Media (New Brunswick, N.J.: Rutgers University Press, 2015).
} 
final one) to infectious viruses. In the 1995 medical disaster film Outbreak, one of the early movies on the dangers of epidemics, a reckless Korean ship crew smuggled a whiteheaded capuchin monkey, the host of a fatal zoonotic pathogen, into US territory. In a more recent apocalyptic film, World War Z (2013), Camp Humphreys, a US military base in Pyungtaek, South Korea, is where the outbreak of a zombie virus is first reported. A former United Nations investigator is dispatched to South Korea to develop a vaccine to save the world. There, he is told how the North Korean dictatorship successfully prevented the spread of the virus: "They pulled the teeth of all 23 million in less than 24 hours. No teeth, no bites." Quite coincidentally, there have been no reported cases of COVID-19 in North Korea so far.

In contrast to the dreadful and dictatorial measure deployed in film by North Korea, the extensive utilization of advanced ICTs has been highlighted as a crucial reason for South Korea's success. A tech-savvy Big-Brother-like society is not incompatible with Confucian collectivist culture. They are likely quite congruent. South Korea, in particular Seoul, has been increasingly portrayed as a futuristic high-tech city in more recent Hollywood films such as Avengers: Endgame (2019), Avengers: Age of Ultron (2015), The Bourne Legacy (2012), Colossal (2016), and Downsizing (2018), to name a few.

The glittery imaginary of the city reflects the changing location of Seoul in global urban networks as well as the changing perception of the city and country in global media industries. South Korea is projected as the most media-saturated and wired nation on earth, articulating its cultural identity with ICTs. This sort of technomythological perception of Korea is exemplarily depicted in the German American sci-fi film Cloud Atlas, an adaptation of the 2004 novel of the same title. One of six stories, "An Orison of Sonmi-451," is set in Neo Seoul ("Nea So Copros" in the book), in an apocalyptic future dated to 2144. In the united Korea, Neo Seoul appears to be a "totally administered society" (in Herbert Marcuse’s terminology) termed a "corpocracy," an Orwellian totalitarian regime that is governed by the Juche ideology - North Korea's governing national ideology — and by hyperconsumerism: the worst combination of North and South Korea. As such, in filmic representations, the Confucian collectivist regime and hyper-techno capitalism consolidate the image of South Korea.

But what about in real life, especially during the pandemic crisis? In the twenty-first century, is it still feasible to identify South Korea as a Confucian society? Or do high-tech measures alone handle the coronavirus? Whereas Korea's ICTs are positively appraised, its Asian traits are blamed. South Korea's IT-based epidemic containment strategies are conceived as a transgression of privacy that would not fit in individual-freedom-based liberal societies such as Western Europe and North America. Herein lies a crucial limitation embodied in the conventional view of binaries: individual versus society, private versus public, nature versus culture, human versus machine, and so on. It oscillates between the two components by simplifying the complex dimensions of Korean society as a choice between civic liberty as an individual freedom and public health driven by technological operation. The view based on this conventional dichotomy hardly grasps the South Korean experience of COVID-19. South Korea as the mediasaturated society would be less the Orwellian society in Nineteen Eighty-Four, based on a monitoring system of hyper-surveillance, than Aldous Huxley's World State in Brave New World, in which, by their own free will, individual citizens accept an intelligence and merit-based social mechanism engineered by the state-of-art technologies. 


\section{Three Ts + Technology}

During the outbreak of COVID-19, the South Korean government quickly identified key health and quarantine measures as the "three Ts" of testing, tracing, and treating: testing as measures to prevent the entry of the virus; tracing as conducting rigorous epidemiological investigations; and treating as the establishment of a patient management system. ${ }^{12}$ The nationwide crisis management system has been reinforced through the experiences of recent disasters. The sinking of the Sewol ferry in 2014, which cost 304 lives, including 250 high school students, sparked grave criticisms about the ineffective —and indifferent-response and continuous political coverups by the government. It ignited nationwide protests with several million participating in 2016, eventually leading to the impeachment and imprisonment of the then-president Park Geun-hey in March 2017. As the current South Korean foreign minister, Kang Kyung-hwa, emphatically stressed, South Korea's quick and preemptive response to the coronavirus outbreak derived from the traumatic experience and memory of the Sewol disaster. ${ }^{13}$ The 2015 outbreak of MERS (Middle East respiratory syndrome) in South Korea, which resulted in 38 deaths out of 186 confirmed cases, also induced the government to reassess and reorganize its disease control system for outbreaks of large-scale epidemics and to support hospitals to set up more negative pressure rooms. These rooms served as-not sufficient yet-essential locations for isolating and treating coronavirus patients during the outbreak this year.

South Korea is a society with a history of disasters and various forms of crisis, ranging from politics to economics to health. The disasters have penetrated every corner of ordinary lives. This time, the country is more prepared. In December 2019, the center-right government conducted a large-scale drill to prepare a response to a fictional outbreak of a disease imported by a South Korean family after a trip to China. ${ }^{14}$ Less than two months after the exercise, Korea's first confirmed case was reported when a person who had visited Wuhan, China, tested positive. Measures exercised during the drill were quickly deployed. The initial response of the government signified that a "developing" country like South Korea is more prone to cope with disasters that require fast processes of decision and practice. "Developed" postindustrial countries seemed to believe they had graduated from this sort of "Asian" epidemic, at least in the initial stage of the outbreak. South Korea, the twelfth-largest economy in the world yet always classified as a "developing" country, has not yet outsourced major manufacturing and production lines abroad, such that it is still able to produce and supply essential personal protective equipment not only to medical staff but to the majority of citizens.

\footnotetext{
${ }^{12}$ Ministry of Economy and Finance of Korea, "Tackling COVID 19: Health, Quarantine and Economic Measures: Korean Experience," March 31, 2020, http://english.moef.go.kr/pc/selectTbPressCenterDtl.do?boardCd=N0001\&seq=4868 (accessed June 6, 2020).

${ }^{13}$ Park Han-na, “38 Workers Killed in Incheon Construction Site Fire,” Korea Herald, April 29, 2020, http://www.koreaherald.com/view.php?ud=20200429000867 (accessed June 6, 2020).

${ }^{14}$ Hyonhee Shin, "South Korea's Emergency Exercise in December Facilitated Coronavirus Testing, Containment," Reuters, March 30, 2020, https:/uk.reuters.com/article/us-health-coronavirus-southkorea-drills-idUKKBN21H0BQ?fbclid=IwAR2fcsKO8RUL0KDkKx2jhCoUatcEpX2tt QzonrZ8Lnpevxibf3Dmg9FO7mg (accessed June 6, 2020).
} 
The previous crisis was also used by the government to relax some legal restrictions. No sooner had MERS diminished than the government revised the Personal Information Protection Act (PIPA), Korea's strict data privacy law. In principle, PIPA prohibits the collection, use, and disclosure of personal data without prior informed consent of the individual. Under the amended Contagious Disease Prevention and Control Act, which overrides PIPA, data can be collected and profiled by public agencies such as the KCDC. ${ }^{15}$ In doing so, the government led the private sector to collect, process, and use large-scale data, facilitating the development of various tracing applications. In particular, partnering with the KT Corporation, Korea's largest telecommunications company, the government provided researchers and app developers with data on levels of foot traffic and international roaming since April 1, 2020, for free. ${ }^{16}$

One of applications that actively employs information provided by the KCDC is Coronavirus Map. Created by a college student during the initial stage of the outbreak, the app informs users of the moment of a confirmed case. Now and Here is an app that calculates a mix of risk factors in surrounding areas when users enter their commuting route. If the user has been in the same place as an infected individual at a similar time, the app suggests when and where a test for infection is available. Another app, Cobaek, sends an alert when users are within 100 meters of a place that an infected individual visited. The app was upgraded to the Cobaek Plus version with the addition of alerts for the availability of publicly provided masks at pharmacies. The app serves to refrain from panic buying or long queues for purchase.

The Korean government went on to develop a mobile app, Self-Quarantine Safety, to monitor the symptoms of inbound travelers. The app allows users to monitor their conditions and conduct self-diagnosis, and it ensures that self-quarantine orders are kept by setting off an alarm when a user ventures outside the designated quarantine area. The app had been installed by approximately 170,000 travelers as of April 9. ${ }^{17}$ A great deal of controversy regarding information privacy arose when installation of the app became mandatory for all inbound travelers, including Korean nationals, on April 1. As of April 13, 91.4 percent of those under self-quarantine had installed the app. Inbound travelers who do not install the mobile application or fail to submit their daily health conditions are tracked down by immigration services using visa information and airline and passenger data. Travelers who fail to use the app as advised receive a notification and warning text messages on the first and second days, respectively. Travelers who show no indication of using the app properly on the third day are contacted by phone. If they still do not comply on the fourth day, they are reported to the police to be tracked down and fined for violations, up to $\$ 2,500$.

The South Korean government justifies the employment of technological contact tracing as it curtails the limitations of interview-based investigations that rely on human memory and the honesty of the interviewees. In April 2017, the government

\footnotetext{
${ }^{15}$ Sangchul Park et al., "Information Technology-Based Tracing Strategy in Response to COVID-19 in South Korea-Privacy Controversies," JAMA 323, no. 21 (2020): 2129.

${ }^{16}$ Government of the Republic of Korea, "Flattening the Curve on COVID-19: How Korea Responded to a Pandemic Using ICT," April 15, 2020, http://overseas.mofa.go.kr/us-houston-en/ $\mathrm{brd} / \mathrm{m} \_5573 /$ view.do?seq $=759765$ (accessed June 6, 2020).

${ }^{17}$ Government of the Republic of Korea, "Flattening the Curve," 35-40.
} 
introduced the Advancement of Smart Quarantine Information System, a quarantine information project that utilizes overseas roaming data to identify those coming into the country from high-risk regions and monitor them during the incubation period of the infection. Now legally supported, the quarantine authorities of Korea are empowered to acquire not only patient statements but also personal information through location tracking, card transactions, and CCTV recordings to trace transmission.

The success of contact tracing reveals how deeply South Korea is a data society. The wide use of credit and debit cards made South Korea a forerunner of a demonetized economy with high proportions of cashless transactions (52 percent of all transactions in 2019). The younger generation is already habituated to virtual payment. More than 60 percent of the 1,280 stores operated by Starbucks Coffee Korea only accept credit cards and mobile payments. The rapid growth of the cashless economy has been expedited by the wide use of smartphones. In 2019, South Korea had one of the world's highest phone ownership rates. Phone locations are automatically recorded with nearperfect accuracy because devices are connected to one to three transceivers at any time. There are approximately 860,000 4G and 5G transceivers densely covering the whole country. Phone companies require all customers to provide their real names and national registry numbers so that they can track nearly everyone by following the location of their phones. CCTV cameras also enable authorities to identify people who have been in contact with infected individuals. In 2016, South Korean cities contained 739,232 public CCTV and 1.5 million private CCTV cameras.

The datafication of epidemiological investigation has been enhanced by the COVID-19 Epidemiological Investigation Support System, a data platform that is designed to support epidemiological surveyors in identifying the transmission routes and places that infected individuals have visited. Through the application of City Data Hub, operating under the National Strategic Smart City R\&D Program, the cloud-based open data hub works to collect, store, process, analyze, and publish the cross-functional data. Since 2018, the KCDC has run the platform in close coordination with the National Police Agency, Credit Finance Association of Korea, three telecommunications companies, and 22 credit card companies. Conducting big data analysis, the platform provides real-time data on infected individuals, including their locations and the time spent there. In this vein, it is no wonder that the level of surveillance has been considerably heightened. Since COVID-19 has been classified as a new infectious disease syndrome in Group 1 of infectious diseases, reporting a patient with an infectious disease to a health center is required under the Mandatory Surveillance System. The disclosed data are categorized by time and region, stored in the Web-Statistics on Surveillance of Infectious Diseases, and shared and publicized by local authorities. ${ }^{18}$

Meticulous logs of the travel and contacts of infected individuals are compiled based on the data. Consider, for example, the level of detail in the logs of patient 64, a 49-year-old female in Gwan-ak Gu, the southwestern district of Seoul. On June 6, 2020, the district office sent me an alert text message stating that patient 64's logs had been uploaded to its blog following a positive test on June 5 after the patient visited a discount store, Richway, where a collective infection took place on May 31:

${ }^{18}$ Government of the Republic of Korea, "Flattening the Curve," 41-46. 
On Sunday May 31, she stayed at home until 18:10; 18:10-18:20 moved on foot; 18:20-18:21 visited a store, Well-Being House (address included) where there was human contact. Disinfection and sterilization were completed. Now safe; 18:21-18:23 moved on foot and visited a fruit store, Sillim Fruits; 18:2318:24 moved on foot and visited a grocery store, Jinheung Supermarket (address included); 18:24 returned home on foot and stayed at home. On Monday June 1, 11:20-12:00 she walked to the Sillim subway station, arrived in the Guro Digital Center station via metro; 12:00-12:30 visited Richway where there were human contacts; 12:30-18:27 walked to the Guro subway station and moved to other district via metro; 18:27-18:38 arrived at the Shillim subway station and moved on foot; 18:38-18:39 visited Ogury Hiper, a grocery store where there were human contacts; 18:39 returned home on foot and stayed at home. On Wednesday June 3, 09:00-09:14 she moved on foot, and 09:14-09:15 visited the Chung Ang pharmacy; 09:32-09:33 visited the Hyungjae fruit store; 09:33 returned home on foot and stayed at home. On Thursday June 4, 10:3011:30 she visited the medical center of Gwan-ak Gu and took a COVID-19 test. On Friday June 5 she tested positive. ${ }^{19}$

The log reconstructed here may seem overly meticulous, but in fact, it is far less detailed than the information gathered. On March 9, Korea's National Human Rights Commission issued a recommendation to ameliorate privacy concerns, suggesting that revealing exceedingly detailed information was unwarranted..$^{20}$ The high level of data sharing about infected individuals raised serious concerns about data privacy. The locations of infected individuals were exhaustively covered by district offices as well as mass media. The granular personal details about infected individuals have been profiled by the general public on various social media networks. Reidentification of individuals prompted widespread internet trolling, in which individuals were blamed and criticized for their reckless, selfish, and negligent behaviors that harmed communities. Tensions between civil society and the state increasingly grew to protect individuals from the centralization of data and the abuse of information power.

\section{Between Individual Freedom and Public Health in a State of Emergency}

It is a crucial point that the COVID-19 crisis has not merely prompted "the intensification of surveillance" in Korea but the "datafication" of society, involving "the transformation of human life into data through processes of quantification, and the generation of different kinds of value from data." 21 The "datafied" tracing system in South Korea has consolidated ICTs and tech companies as institutions essential to the basic functioning of the quarantine society. As Nick Couldry warns, the emergence of a new social order

\footnotetext{
${ }^{19}$ Gwan-ak Gu District Office, "Log of Patient 64," Gwan-ak Gu Covid-19 Status (blog), June 6, 2020, https://blog.naver.com/gwanak_gu (accessed June 7, 2020).

${ }^{20}$ Park et al., "Information Technology-Based Tracing Strategy," 2130.

${ }^{21}$ João Carlos Magalhães and Nick Couldry, "Tech Giants Are Using This Crisis to Colonize the Welfare System," Jacobin, April 27, 2020, https:/www.jacobinmag.com/2020/04/tech-giants-coronavirus-pandemic-welfare-surveillance (accessed June 6, 2020).
} 
is centered on "data colonialism." 22 Yet it is still debatable to what extent the South Korean government's data policy during the pandemic prioritized public health over individual privacy and to what degree South Korean citizens accepted the loss of privacy as a necessary trade-off. ${ }^{23}$ As shown earlier, while critically questioning Korea's deployment of surveillance technologies, individual privacy and public health are starkly contrasted as incompatible and an either/or scenario. ${ }^{24}$

This sort of binary discourse on Korean society pays little attention to the operation of the health care system while discussing the issue of "public" health. With a universal health care system, South Korea ranked first in the OECD for health care access and was rated as the fourth most efficient health care system in 2015. According to the Health Care Index by Country in 2020, South Korea ranked second after Taiwan. ${ }^{25}$ Anyone with a fever can request a COVID-19 test, which is free to the public. When doctors initially believe that a person is at risk based on where they have been or whom they have contacted, they collect samples from their nose and throat for analysis. The test takes 10 minutes or less. The person receives a text message with the result the next day. It is less likely that an individual would go for a test and treatment if an enormous medical bill would be expected. A tracing app can track down people, but it cannot enable them to visit a test center. The health care system does. South Korean citizens willingly accept the experiment of testing and tracing while appreciating and securing public and communal systems of treating. In this distinctive way, the South Korean experiment grapples with the relationship between individual freedom and public health, showing that the two key elements are not incompatible but complementary.

Despite its noticeably flattened curve, the COVID-19 crisis in Korea is ongoing. In fact, the KCDC is highly concerned about the possibility of the second wave in the fall. It is thus far too early to say whether the South Korean approach was ultimately successful. My observations are equally tentative. Yet I wonder whether the success that South Korea has achieved so far stems from the fact that the state of emergency has been embodied in key social dimensions in a particular way. In his essay "On the Concept of History," written in 1940 just before his death, Walter Benjamin, the Jewish German cultural critic, noted that "the tradition of the oppressed teaches us that the 'state of emergency' in which we live is not the exception but the rule. We must attain to a conception of history that accords with this insight. Then we will clearly see that it is our task to bring about a real state of emergency, and this will improve our position in the struggle against fascism." ${ }^{26}$

\footnotetext{
${ }^{22}$ Nick Couldry, The Costs of Connection: How Data is Colonizing Human Life and Appropriating It for Capitalism (Stanford, Calif.: Stanford University Press, 2019).

${ }^{23}$ Justin Fendos, "How Surveillance Technology Powered South Korea's COVID-19 Response," Tech Stream, April 29, 2020, https://www.brookings.edu/techstream/how-surveillance-technologypowered-south-koreas-covid-19-response/ (accessed June 7, 2020).

${ }^{24}$ Eun A. Jo, "South Korea’s Experiment in Pandemic Surveillance," The Diplomat, April 13, 2020, https:/thediplomat.com/2020/04/south-koreas-experiment-in-pandemic-surveillance/ (accessed June 7, 2020).

${ }^{25}$ Numbeo, "Health Care Index by Country 2020 Mid-Year," https://www.numbeo.com/health-care/ rankings_by_country.jsp (accessed June 6, 2020).

${ }^{26}$ Walter Benjamin, "On the Concept of History," in Walter Benjamin: Selected Writings, vol. VI, 1938-1940, eds. Howard Eiland and Michael W. Jennings (Cambridge, Mass.: Harvard University Press, 2006), 392.
} 
Clearly, the implications of this cannot be taken directly without careful consideration of its political context involving the height of the calamitous self-destruction of fascism. Viewed from Benjamin's critical perspective, South Korea is a never-ending developing, progressing, and advancing country that has been and will be going through more crises. It is in a permanent state of emergency: the establishment of the republic-in-exile in 1919, the decolonization from Japanese imperialism, the brutal three-year civil war between the North and South that cost millions of lives, the remaining hostile Cold war relations with North Korea, several military coups and dictatorships, the financial crisis, recurring largescale accidents costing hundreds of lives, and so on. In the permanent state of emergency, the crisis is "the rule," especially for the oppressed.

On April 29, 2020, there were no domestic confirmed cases of COVID-19, but 38 workers were killed in a fire that broke out at a construction site for a logistics warehouse in Icheon, Gyeonggi Province, 50 miles southeast of Seoul. In the very same city, an almost identical accident took place a few years ago. On June 6, 2008, forty workers were killed in a fire at a refrigeration warehouse. ${ }^{27}$ In 2018, 971 South Korean workers died in workplace accidents, and every day, 2.7 workers died in industrial accidents. In 2015, the occupational fatality was 10.1 per 100,000 employees, among the highest in the OECD. ${ }^{28}$ For workers, South Korea is a state of emergency. In 2018, the poverty rate of senior citizens was the highest in the OECD. For older people, South Korea is a state of emergency. In the same year, the total fertility rate was 0.98, the lowest in the world. According to the World Economic Forum, South Korea ranks 124th out of 149 countries in terms of economic participation and opportunity for women. Given this gender inequality, South Korea is a state of emergency for women. Migrant workers in South Korea are largely excluded from the government's handling of the coronavirus. In mask rationing and monetary coronavirus relief handouts, the majority of foreigners are left out of consideration. For migrant workers, South Korea is a state of emergency.

The current crisis of the COVID-19 pandemic is not a breakdown of normality but a continuation of the state of emergency that rules a developing country like South Korea. All of the social problems are legitimized as inevitable within the process of development and progress. This ideology serves to normalize the state of emergency and perpetuate the crisis for the marginalized, vulnerable and unprotected citizens. We cannot go back to normal because normal is a state of emergency. A "real" state of emergency is required to stop the "normal" state of emergency in which South Korea exists. Maybe we are passing through a long tunnel during this pandemic. No one is sure whether it will be another pandemonium or the less fatal, painful, degenerate state of emergency. It may depend on how we pass through it.

\section{Acknowledgments}

This study was financially supported in part by the Institute of Communication Research, Seoul National University.

\footnotetext{
${ }^{27}$ Ahn Sung-mi, "Seoul Trauma behind Seoul's Quick Response to Virus Crisis," Korea Herald, April 14, 2020, http://www.koreaherald.com/view.php?ud=20200414000720\&fbclid=IwAR034STtEM6e3GXEZB_GQEldTIT-iC_PvABX1Bve40rO7YrDOcM-ZaRSHFw (accessed June 6, 2020). ${ }^{28}$ "S Korea Industry's Deadly Conditions Built on Culture of Cover-Up," Financial Times, December $6,2017$.
} 